\title{
Exceptional penetrating orbital injury that spared the eye globe
}

\author{
Ines Leal, ${ }_{1}^{1}$ Ines Caldeira, ${ }^{2}$ Rita Sousa, ${ }^{2}$ Filomena Pinto ${ }^{1,3}$
}

${ }^{1}$ Faculdade de Medicina de Lisboa, Lisbon, Portugal ${ }^{2}$ Department of Neuroradiology, Hospital de Santa Maria, Lisbon, Portugal ${ }^{3}$ Department of Ophthalmology, Hospital de Santa Maria, Lisbon, Portugal

\section{Correspondence to} Dr Ines Leal, inescardosoleal@gmail.com

Accepted 1 March 2015
CrossMark

To cite: Leal I, Caldeira I, Sousa R, et al. BMJ Case Rep Published online: [please include Day Month Year] doi:10.1136/bcr-2014209053

\section{DESCRIPTION}

A 29-year-old man presented to the emergency room after suffering an intentional right orbital penetrating injury with a knife. Cranial and orbital volumetric CT scans (figures 1 and 2-three dimensional reformatting images) were obtained in an emergency setting and show the knife entry point through the right superior and external supraorbital region. The knife penetration follows an anteroposterior axis from right to left and from superior to inferior. Distally, on the left side, the knife penetrates the infratemporal fossa, missing the internal carotid artery by $5.6 \mathrm{~mm}$ and hitting the zygotic bone. Proximal to the entry point, the track passes between the right ocular bulb and the external rectus muscle, and goes through the intraconal fat,

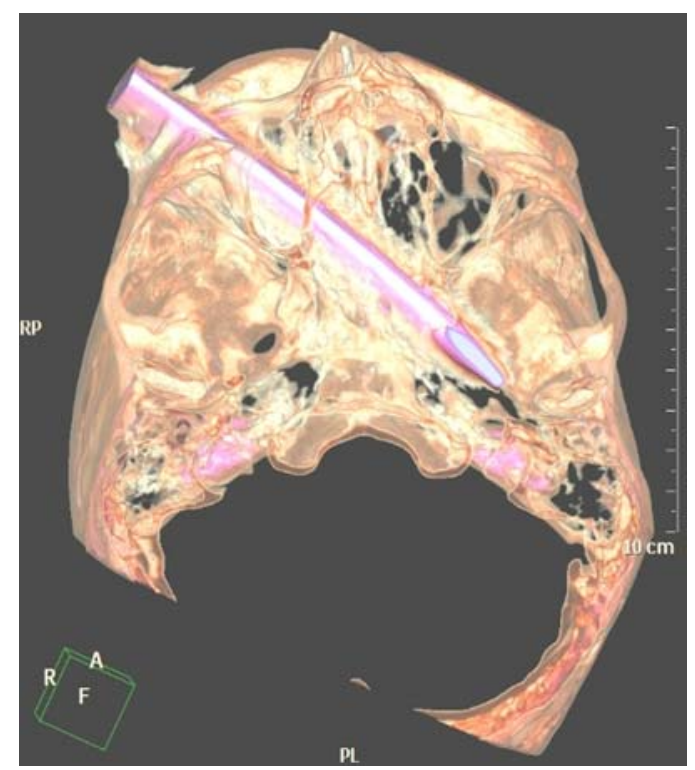

Figure 1 Cranial and orbital volumetric CT scans-a three-dimensional reformatting image.

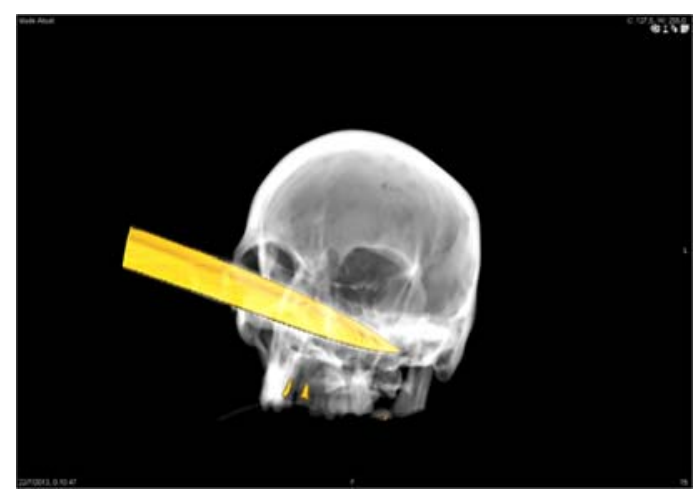

Figure 2 Cranial and orbital volumetric CT scans-a three-dimensional reformatting image.

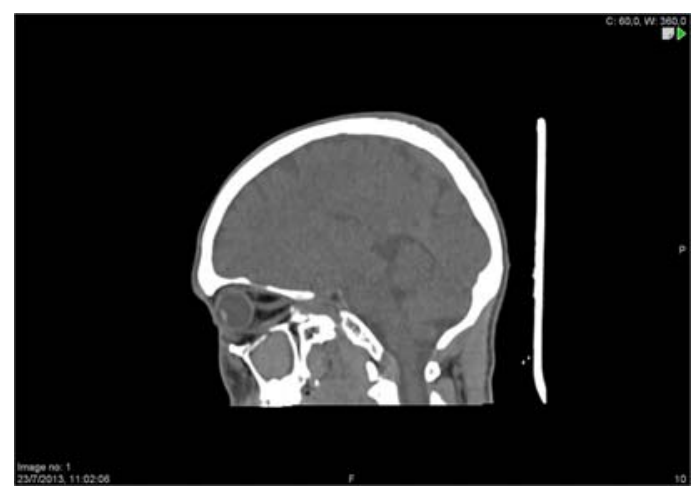

Figure 3 Volumetric postoperative CT scan-a sagittal plane.

without coming into contact with the optic nerve. There is apparent disruption of the inferior rectus muscle and penetration of the inferior orbital plate, lamina papyracea, ethmoidal labyrinth, left vidian canal and left infratemporal fossa. There are no apparent traumatic brain lesions, despite the artefacts caused by the knife. A multidisciplinary team performed surgery to remove the knife in an uneventful procedure. Twenty-four hours after the procedure, ophthalmological examination revealed a normotonic ocular globe with no signs of perforation. Visual acuities and ocular motility were grossly preserved. Volumetric postoperative CT scans (figure 3-sagittal plane) show right orbital pavement fractures and right maxillary and ethmoidal hemosinus. However, the right ocular globe and the optic nerve are unremarkable. Although strikingly surprising, these exceptional images substantiate that the ocular globe may be spared after an important penetrating orbital injury. ${ }^{12}$

\section{Learning points}

- Orbital perforating and penetrating trauma are sight-threatening injuries generally due to sharp or high-velocity objects. ${ }^{3}$

- Visual prognosis is usually poor due to severe damage to globe structures that generally follows these traumas; however, in rare cases, orbital injuries may spare the globe, culminating in a much better visual outcome. $^{12}$

- Orbital CT scans may help predict visual prognosis in orbital perforating and penetrating injuries, which emphasises the need for a multidisciplinary team in care management of ophthalmological trauma. ${ }^{3}$ 
Contributors IL wrote the manuscript and was the attending physician. IC and RS were the neuroradiologists who obtained, interpreted and reformatted the images. FP approved the final manuscript.

Competing interests None.

Patient consent Obtained.

Provenance and peer review Not commissioned; externally peer reviewed.

\section{REFERENCES}

1 Custer PL, Ken TL. Pitfalls of ophthalmic radiographic imaging. Curr Opin Ophthalmol 2014;25:432-5.

2 Betts AM, O'Brien WT, Davies BW, et al. A systematic approach to CT evaluation of orbital trauma. Emerg Radiol 2014;21:511-31.

3 Sung EK, Nadgir RN, Fujita A, et al. Injuries to the globe: what can the radiologist offer? Radiographics 2014;34:764-76.

Copyright 2015 BMJ Publishing Group. All rights reserved. For permission to reuse any of this content visit http://group.bmj.com/group/rights-licensing/permissions.

BMJ Case Report Fellows may re-use this article for personal use and teaching without any further permission.

Become a Fellow of BMJ Case Reports today and you can:

- Submit as many cases as you like

- Enjoy fast sympathetic peer review and rapid publication of accepted articles

- Access all the published articles

- Re-use any of the published material for personal use and teaching without further permission

For information on Institutional Fellowships contact consortiasales@bmjgroup.com

Visit casereports.bmj.com for more articles like this and to become a Fellow 